DOI: $10.22559 /$ folklor.879

folklor/edebiyat, cilt:25, sayı:99, 2019/3

\title{
Kamel Daoud'un Meursault, Contre-Enquête Adlı Yapıtında Efendi-Köle Diyalektiği
}

\author{
The Master-Slave Dialectic in Kamel Daoud's Novel Entitled \\ Meursault, Contre-Enquête
}

\section{Ayşe Tomat YıImaz*}

\begin{abstract}
Öz
İnsanlık tarihi, insanların, toplumların ya da ülkelerin kendi aralarındaki güç savaşlarına dayanır. Kendilerini karşılarındakine kabul ettirmek amacıyla girdikleri her bir savaşın sonunda da yaşamını kaybetmeyi göze alacak derecede yürekli olan kişi efendi konumuna geçerken, korkuları nedeniyle başlangıçtaki amacından vazgeçen özne köle olur. Başka bir deyişle, güçlerin eşit olmadığı bir ilişkinin sonunda insan ya efendi ya da köle olarak yer alır. Efendi köle üzerinde egemen bir güç olarak yaşarken, köle de efendinin buyruğu altında yaşamını devam ettirir. Doğada bulunan nesneleri efendisi için dönüştürüp onun tüketimine sunan köle başlangıçta bağımlı bir bilinç gibi görülür. Ancak çalıştıkça gücünün ayrımına varan, doğayı dönüştürdükçe de kendi üstünlüğünü anlayan köle zaman içinde büyük bir evrim geçirir. Böylelikle özgürlüğün kapısını kendi elleriyle aralayıp efendi olma yolunda ilerler. Bu çalışmada amaç, Albert Camus'nün Yabancı ve Kamel Daoud'un Meursault, contre-enquête adlı yapıtlarının Georg Wilhelm Friedrich Hegel'in efendi-köle diyalektiği bağlamında yorumlanmasıdır. İlk romanda köle olarak yer alan öznenin ikinci romanda efendi konumuna evrilmesi ise araştırmanın sonucunu
\end{abstract}

Dr., École Normale Supérieure de Lyon, Yabancı Diller Bölümü. ayse.tomat-yilmaz@ens-lyon.fr Dr., Lyon 2 Üniversitesi, Arap, İslami Çalışmalar Merkezi. ayse.tomat-yilmaz@ens-lyon.fr 
oluşturur. Söz konusu romanlar metinlerarasılık açısından birçok çalışmaya konu olmalarına karşın, diyalektik bağlamda incelenmediklerinden, bu çalışmanın kendisinden sonra yapılacak olan araştırmalara 1şık tutması öngörülmektedir.

Anahtar sözcükler: Kamel Daoud, Albert Camus, Hegel, efendi, köle, efendi-köle diyalektiği

\begin{abstract}
The history of humanity is based on the power wars between people, societies or countries themselves. At the end of every war they enter to prove themselves to other side, the person, who is courageous enough to lose his life, becomes the master while the person, who gives up his initial purpose because of his fears becomes a slave. In other words, at the end of a relationship, where the two forces aren't equal, the person is either a master or a slave. While the master lives as a sovereign over the slave, the slave lives under the command of his master. The slave, who transforms objects in nature to his master and presents them to his consumption, is initially seen as a dependent consciousness. However, the slave, who distinguishes his power by working and who understands his superiority by transforming nature, evolves largely. In this way, the slave opens the door to freedom with his/her own hands and moves towards becoming a master. The aim of this study is to interpret Albert Camus's The Stranger and Kamel Daoud's The Meursault Investigation in the context of the master-slave dialectic of Georg Wilhelm Friedrich Hegel. The result of this research is the evolution of subject who takes place as a slave in the first novel and who becomes a master in the second novel. These novels are interpreted in the context of intertextuality but they are not studied in a dialectical context. Thus, it is foreseen that this study will be initiator of researches which will be carried out after.
\end{abstract}

Keywords: Kamel Daoud, Albert Camus, Hegel, master, slave, the master-slave dialectic

\title{
Giriş
}

Bir insanın herhangi bir nesneye ya da varlığa olan gereksinimi, isteği, dileği, arzusu doğduğu günden yaşamının sonuna kadar durmaksızın devam eder çünkü insan, doğası gereği doyumsuz bir varlıktır. İnsanın yaratılışıyla birlikte türeyen bu açlığı başka bir deyişle doyumsuz arzusu genellikle kendi içgüdüleri doğrultusunda ortaya çıkmaz. Söz konusu nesneyi ya da varlığı kendisine amaç olarak belirlemesinin nedeni genellikle başka bir kişiye öykünmesidir. Nitekim, gerçek yaşamdaki insanlar ya da kurmaca yapıtlarda yer alan kişiler yüzeysel bir bakışla değil de daha dikkatli bir biçimde irdelendiğinde; özne-nesne etkileşiminde görüş alanının dışında tuttuğu bir dolayımlayıcı kavramının varlığından söz etmemek olanaksizdir. 
Kibirli bir kişiyi bir nesneyi arzulamaya ikna etmek için aynı nesnenin belirli bir itibarı olan üçüncü kişi tarafından arzulanmış olması yeterlidir. Dolayımlayıcı burada bir rakiptir, kibir önce bu rakibin rakip olarak ortaya çıkmasına neden olmuş, onun varlığını dilemiştir, sonra da onun yenilmesini istemiştir (Girard, 2007: 27).

$\mathrm{Bu}$ bakışla, insanın isteğinin gerçekten tanınması, bilinmesi ya da kabul görmesi için onun başka bir benlik tarafından da arzulanması gerektiği açıktır. Başka bir insanın arzusuna yönelen insansal istek, karşısındaki insanı ya da onun arzusunu yok etmeyi düşlemez; onun tek dileği, karşısındaki varlığın onun buyruklarına uyması, başka bir deyişle kendisini tanımasıdır. Georg Wilhelm Friedrich Hegel'i en iyi yorumlayanlar arasında yerini alan Rus asıllı Fransız filozof Alexandre Kojève "bir başkasının isteğini istemek, aslında, kendi değerimin ya da "temsil ettiğim" değerin, bu başkası tarafından istenen değer olmasını istemektir" (Kojève, 2001: 83) diyerek bu durumu açıklar.

İnsanın kendisinin farkındalığı ya da kişisel farkındalık olarak tanımlanabilen özbilinç kavramının da gereksinimini ya da eksikliğini başka insanların istekleri aracılığıyla gidermeye çalıştığı belirtilmelidir. "Özbilinç, kendinde olan eksikliği bir başkasında bulacaktır. Bir başkasının varlığıyla kendinde eksik olanı tamamlayacak, bir başkasının varlığı aracılığıyla kendi varlığını oluşturacak, benlik duygusunu, öz saygınlığını ve aynı zamanda özpekinliğini kazanacaktır. Bu açıdan ancak istek ona kendiliğini geri verecek, insan varlığının gerçekleşmesine olanak sağlayacaktır” (Özçınar, 2007: 236). Görüldüğü gibi, tıpk1 insansal istekte olduğu gibi özbilinç de ancak kendisine dolayımlayıcı olarak belirlediği başka istekler ya da bilinçler sayesinde varlığını kanıtlayabilir.

Alman düşünür Georg Wilhelm Friedrich Hegel; insanın özbilincinin tam anlamıyla oluşabilmesi için istek kavramıyla birlikte göz pekliğinin de var olması gerektiğini vurgular. Sonucunun ölümle bitme olasılığına karşın, yine de girilen savaşta hiç korkmadan çaba gösterebilmenin önemine dikkat çeker. Onun düşüncelerine göre; insanın özbilinç sahibi olabilmesinin yolu, isteğini ölümü bile göze alarak tanıtmaya çalışmasından geçer. Kısacası insan, karşısındakini yok etmekten çekinmediği, ondan ya da ölümden korkmadığı sürece özvarlığını oluşturabilir.

Özgürlüğün, özvarlığın ya da özbilincin kazanılmasının istek kavramının yanı sıra göz pekliği ile bağlantılı olduğunu belirten Hegel, felsefesinin anahtar noktalarından biri olan efendi-köle diyalektiğini de bu dayanağa oturtur. İki karşıt bilincin oluşturduğu diyalektiğini insanların yürekliliğiyle ilişkilendirir. $\mathrm{O}$, insanın, kendisini ya da bir insan olduğunu çevresine kabul ettirebilmesi için büyük bir savaşım vermesi gerektiğine dikkat çeker. Başka bir deyişle, insan kendi öznel gerçekliğini nesnel bir gerçekliğe dönüştürebilmek amacıyla savaşmak zorundadır "çünkü kendi kendilerinin pekinliğini, kendileri için olmayı, başkasında ve kendilerinde gerçekliğe yükseltmelidirler” (Hegel, 2011: 125).

Kendi yaşamlarını kaybetme olasılığını bilmelerine karşın, her iki ayrı özne bu savaşta yerlerini alırlar. Söz konusu iki varlığın ölümüne girdikleri bu savaşta, her biri karşısındakini yok edilmesi gereken bir düşman olarak görür çünkü gücünü ve gözü pekliğini kanıtlayan özne düşmanı tarafından bilinip tanınacak ve büyük bir saygınlık kazanacaktır. Ancak savaş sırasında öznelerden biri yaşamını kaybetmeyi göze alamaz, karşısındakinin değerini kabullenerek kendi amacından uzaklaşır. Diğer özne ise başlangıçtaki amacından vazgeçen bu 
öznenin yaşamını bağışlarken aynı zamanda onu köleleştirir. Nitekim yaşamını kaybetmeyi göze alacak derecede yürekli olan kişi efendi konumuna geçerken, korkuları nedeniyle savaşmaktan vazgeçen kişi de köle olur (Bumin, 2010: 36-37).

Son derece güç bir savaşta, "yaşamlarını ortaya koyan ve onu hem kendilerinde hem de ötekinde küçümseyen” (Hegel, 2011: 126) kısacası bilerek ve isteyerek kendilerini tehlikeye atan efendi ve kölenin ilişkisi bundan böyle nesneler üzerinden gerçekleşir. Doğada bulunan nesneler artık efendi için hiçbir bağımlılık oluşturmaz çünkü köle bütün bu nesneleri efendisinin dileği doğrultusunda onun için işler. Efendi, kölenin dönüştürüp kendisine sunduğu nesneleri tüketirken, kölenin böyle bir ayrıcalığı yoktur. Nitekim, savaşta korkmadan mücadele eden efendi köle üzerindeki güç olarak yaşamını devam ettirirken, ölmeyi göze alamayan köle de sadece efendinin buyruğu altında yaşar (Bumin, 2010:39).

Kimilerinin beğenip değer verdiği kimilerinin de acımasızca eleştirdiği Hegel'in efendiköle diyalektiğinin görüngülerinin günlük yaşamda olduğu gibi, yazın yapıtlarında da yerini alması olasıdır. Okurlara sonsuz bir ortam sunan kurgusal yapıtlar kimi zaman gerçek yaşamdan çok daha fazlasını gözler önüne sererler. Bu nedenle yapıtları sadece bir roman, hikaye, öykü olarak okuyup değerlendirmek yerine onları türlü bakış açıları doğrultusunda açımlamak gerekir. Bu çalışmada da Kamel Daoud'un Meursault, contre-enquête adlı romanı Hegel'in efendi-köle diyalektiği bağlamında yorumlanacaktır. Söz konusu roman metinlerarasılık açısından birçok çalışmaya konu olmasına karşın diyalektik bağlamda incelenmediğinden, bu çalışmanın kendisinden sonra yapılacak olan araştırmalara 1şık tutması öngörülmektedir.

\section{Yabancı'da efendi-köle izleri}

Birçok toplumun, devletin, ülkenin ya da insanın kendi aralarında güç savaşlarına girdiği ve her bir savaşın sonunda da öznelerden birinin efendi konumuna yükseldiği, diğerinin ise boyun eğmek zorunda kalan köle olduğu herkesçe bilinir. Burada öncelikle üzerinde durulması gereken nokta, askeri ve ekonomik bakımdan güçlü devletlerin başka devletler üzerinde zora dayanarak kurdukları düzen olarak tanımlanan sömürgecilik savaşıdır. Haçlı Seferleri aracılığıyla ortaya çıktığı belirtilen ve XV. yüzyılda coğrafi keşifler ile daha da güçlendiği öne sürülen Avrupa yayılmacılığı zaman içinde etkisini artırmaya devam eder. XIX. yüzyıla gelindiğinde ise, askeri bakımdan güçlenmeye başlayan Fransızlar da yeni kaynak arayışına girerler ve Cezayir'e karşı büyük bir savaş açarlar. "Hegel'e göre, «kendini kabul ettirme» isteğinin yol açacağı eylem, bilinçlerarası ilişkinin bu aşamasında, savaştan başka bir şey olamaz. O halde, özetlersek, özbilincin doğuşu kaçınılmaz olarak özbilinçler arası ilişkiden geçecek ve bu ilişkinin ilk biçimi, yine kaçınılmaz olarak, "kendini kabul ettirme uğruna savaş" olacaktır. Hegel'in ünlü Köle-Efendi diyalektiği, işte bu savaşın ve sonuçlarının diyalektiğidir" (Bumin, 2010:36).

Yaşamları uğruna savaşa giren Fransızlar da Cezayirliler de kendi özbilinçlerini gerçekleştirmek için karşılarındakinin varlığını yok etmeyi amaçlarlar. Ancak kendi bilinçlerinin karşılarındakinin bilinci aracılığıyla tanınacağının ayrımında olduklarından onu yeryüzünden tamamen silmeyi de istemezler. Fransızlar ve Araplar arasında kendi gücünü karşıdakine 
kabul ettirmek amacıyla ortaya çıkan bu savaşı Fransızlar kazanırlar, kendilerinden önce Osmanlı egemenliğinde yaşayan Cezayir'i 1830 yılında ele geçirirler ve yüz otuz iki yıl boyunca buradaki egemenliklerini sürdürürler. Büyük bir başarı elde eden Fransızlar savaş sonunda efendi konumuna geçerlerken, kaybeden Araplar da köle olarak adlandırılırlar. (...) İki karşıt bilinç şekli olarak vardırlar; biri özü kendi -için- olmak olan bağımsız bilinç, öteki özü bir başkası için yaşamak ya da olmak olan bağımlı bilinçtir; birincisi Efendi, ikincisi Köledir. (Hegel, 2011: 126).

Efendi konumundaki Fransızlar egemenliklerini kabul ettirdikten hemen sonra, artık bağımlı bir bilinç olarak yaşamlarına devam etmek zorunda olan Araplar karşısında, yerleşimci bir politika uygulamaya başlarlar. Bu amaçla Fransız yerleşimcileri Cezayir'e getirirler böylece günden güne Araplar üzerinde sayı bakımından da büyük bir üstünlük kurarlar. Fransız sömürgeciliği boyunca Avrupa'dan Cezayir'e giden ve orada yaşamaya başlayan bu yerleşimciler "kara ayak" (pied-noir) olarak adlandırılırlar. Söz konusu dönemde, ataları Alsas'tan Cezayir'e göç eden Albert Camus de "kara ayak”tır. 1913 yılında Cezayir'de doğan Camus yoksul bir ailenin çocuğu olmasına karşın, eğitim olanağı yakalayan şanslı çocuklardandır. Zaten kendi ülkelerinde yoksulluk içinde yaşayan bütün yerleşimciler sömürge ülkesinde daha iyi yaşam koşullarına sahiptirler. Başka bir deyişle sömürge ülkesinde yaşayan sömürgeciler ne kadar yoksul olurlarsa olsunlar, sömürülenlerin varsıllarından bile daha iyi olanaklar elde ederler. Camus de bu ayrıcalığı sonuna kadar kullanır; ilkokulu ve liseyi başarıyla tamamladıktan sonra Cezayir Üniversitesi'ne girmeye hak kazanır. Sağlık sorunları nedeniyle okulunu bitiremeyen Camus 1942 yılında kaleme aldığı Yabancı (L'Étranger) adlı romanıyla büyük ses getirirken dikkatleri üzerinde toplamayı başarır.

1960’lı y1llarda Julia Kristeva, Roland Barthes, Gérard Genette gibi araştırmacılar metinlerarasılık olarak adlandırdıkları yeni bir kavram öne sürerler. Zaman içinde kuramlaştırdıkları metinlerarasılık aracılığıyla yapıtların kendilerinden önce yazılmış olan metinlerden izler taşıdığını, yazarların bu metinleri ele alıp dönüştürdüklerini dile getirirler. Ortaya çıkan her bir yapıtın kendisinden önce yayımlanmış olanlarla ilintisi olduğunu belirtirler. Bu bağlamda, Kamel Daoud'un Meursault, contre-enquête adlı romanının ele alınacağı söz konusu çalışmada, öncelikle Albert Camus'nün Yabancı adlı romanına değinmek yerinde olacaktır çünkü Daoud “Camus'nün romanındaki gerçeklikleri iç içe geçiren ve metinlerarası özellikler taşıyan bir yapıt ortaya koyar” (Kartal Güngör, 2017: 278).

Yabancı'nın ana izleğini; Cezayir'de bir kamu kurumunda çalışan Meursault adındaki genç bir adamın yaşadıkları oluşturur. Roman, Meursault'nun yaşlılar evinde kalan annesinin yaşamını yitirmesiyle başlar. Meursault annesinin ölümü nedeniyle işinden izin alıp onun cenaze törenine katılsa da oradaki tepkisizliği nedeniyle büyük dikkat çeker. Annesi için bir damla gözyaşı bile akıtmaz ve sanki hiçbir şey olmamış gibi yaşamına devam eder; zamanını kız arkadaşı Marie ile birlikte eğlenerek geçirir. Annesinin ölümünün üzerinden biraz zaman geçtikten sonra, bir gün, Meursault, Marie ve arkadaşı Raymond ile gittiği deniz kenarında birinin ölümüne neden olur. Birini öldürdüğü için sorgulanan Meursault, aslında annesinin ölümündeki kayıtsızlığı nedeniyle yargılanır ve ölüm cezasına çarptırılır. Nitekim yapıt onun iç hesaplaşmaları, dış dünya ile arasına koyduğu uzaklığg, hem kendisine hem de topluma yabancılaşması ekseninde son bulur. 
$\mathrm{Bu}$ roman sömürgeci/sömürülen, efendi/köle ilişkisi bağlamında irdelendiğinde, Camus'nün ya da Meursault'nun doğup büyüdükleri sömürge ülkesinde büyük olanaklar elde ettiklerinin göstergelerini bulmak olanaklıdır. Örneğin, eğer yazar daha ilk satırlarında romanın Cezayir'de geçtiğini belirtmeseydi, okur anlatılanların Fransa'nın herhangi bir kentinde geçtiğini düşünebilirdi. Romanın başkişisi Meursault'nun mahallenin ana caddesine bakan odasından gördükleri bu durumu kanıtlar niteliktedir. (...) gezinmeye çıkan ailelerdi: Önden pantolonları dizkapaklarının üstünde, yeni elbiselerini yadırgayan, gemici kılıklı iki oğlan çocuğu ile, kocaman pembe kurdeleli, parlak siyah ayakkabılı bir kız çocuğu geliyordu. Onların arkasından, açık kahverengi ipek fistanl, iriyarı anneleriyle, uzaktan tanıdı̆̆ım siska, zarif bir adam olan babaları geliyordu. Adamın başında hasır şapka, boynunda papyon kravat, elinde bir baston vardl... Küçük ceplerine markalar işlenmişti... (Camus, 2006: 28). Fransızların efendi konumunda yaşadıkları bu toplumda Meursault'nun betimlediği kişiler de kendisi gibi ayrıcalıklılardır. Köle olarak yaşamlarını devam ettiren sömürülenlerin bırakın böylesine güzel giyecekleri, gereksinimlerini karşılamak için yeterli yiyecekleri bile yoktur. Bunun nedeni kölenin artık nesneyi tüketememesidir; o nesneyi sadece efendisi için dönüştürür. Savaşta ölmeyi göze alamadığı için artık efendinin ve doğanın kölesi olarak yaşamını devam ettirmektedir (Bumin, 2010:39).

Romanın Cezayir'de değil de Fransa'da geçiyormuş gibi bir izlenim yaratmasının bir diğer göstergesi de başkişi Meursault'nun yaşamıdır. O, tıpkı Fransa'da oturan bir Fransız gibi yaşar; köle olarak görülen sömürülenler bir lokma yiyecek için var güçleriyle çalışırlarken, Meursault tam bir efendidir. Çikolatasını yer, sigarasını içer, kahvesinden şarabına dilediği içeceği tüketir, bilardo oynar, sinemaya gider, sevgilisiyle birlikte denizde yüzer, onunla güneşlenip eğlenir. Görüldüğü gibi köle ya da sömürülenler durmaksızın çalışıp üretmelerine karşın, efendi ya da sömürgeciler hiçbir çaba göstermeden sadece diğerlerinin ürettiklerini sahiplenirler.

Diyalektiğin her iki ucunun karşısındaki tarafından tanınma/kabul edilme durumu ele alındığında ise, efendi ve kölenin bu eylemi tam olarak gerçekleştiremedikleri görülür çünkü söz konusu durumun karşılıklı olması gerekmektedir. Ancak burada kabul edilme tek yönlüdür; efendi kendi özbilincine ulaşmış olsa da köleyi özbilinç olarak görmez. Efendinin gerçek olarak kabul edilmiş olması için, kendisi de özbilinç olan bir başka varlık tarafından kabul görmesi gerekir. Ama bu neredeyse olanaksızdır; kölenin kendisini kabul ettirmesi anlamına geldiğinden efendinin efendiliğiyle çelişir. "Böylece, başlangıçta (savaşa girerken) amaçladığı noktaya yani "bir insan tarafından kabul edilmiş bir insan olma" noktasına ulaşamayan efendinin gerçek doyuma ulaşması imkânsızdır. Efendinin tragedyası, onun içinde bulunduğu açmaz, o halde, ortadadır" (Bumin, 2010: 40).

Gerçekten de efendi olarak tanımlanan sömürgeciler köle konumundaki sömürülenleri genellikle küçümserler; onları hem kendi kimliklerinden uzaklaştırıp Fransızlaştırmaya çalışırlar hem de hiçbir zaman kendi içlerine kabul etmezler. Bunun nedeni kendilerini son derece aydın ve uygar olarak görmeleridir. Onlara göre; "bir Batılılar bir de Şarklılar vardır. Batılılar egemendir, Şarklılara da birinin egemen olması gerekir; bu, çoğu zaman, topraklarının işgal edilmesi, içişlerinin titizlikle denetlenmesi, kişilikleri ile hazinelerinin herhangi bir Batılı gücün tasarrufuna girmesi anlamına gelir" (Said, 2013: 45 - 46). Söz konusu romanda 
da sömürülenlerin sömürgeciler tarafından aşağılandıkları açıktır; Cezayirliler her olanakta küçümsenirlerken ikinci sınıf insan olarak bile kabul edilmezler. Bu durumun en belirgin göstergelerinden biri yazarın Cezayir'de yaşayan halkı tanımlamada kullandığı adlandırmadır çünkü Camus yapıt boyunca Arap adını birçok kez tekrarlar. Onun yapıtında Arap'ın bir adı yoktur; o roman boyunca varlığını sadece Arap olarak sürdürür.

Burada, üzerinde durulması gereken bir başka nokta da Meursault'nun bir Arap'1 öldürmesidir. Raymond ve Marie ile birlikte eğlenmek için gittikleri deniz kenarında, Raymond'un daha önceden sorun yaşadığı Araplarla karşılaşması üzerine bir dövüş çıkar. Kolu deşilen, dudağı yarılan Raymond doktora gitmek zorunda kalır; iyi olduğunu öğrenir öğrenmez de öç almak amacıyla kumsala gider ancak Meursault onun elindeki tabancayı alır ve onu yatıştırmayı başarır. Daha sonra arkadaşını eve götürür ama kendisi sıcaktan ve yaşananlardan bunaldığı için bir kez daha kumsalın yolunu tutar. Uzun süre amaçsızca yürüdükten sonra Raymond'u yaralayan kişiyle karşılaşır; kendisini gören Arap olduğu yerde doğrulup hemen elini cebine sokarken, Meursault da az önce arkadaşından aldığı tabancaya sımsıkı sarılır. Ancak Arap yeniden sırtüstü yatınca, Meursault bulunduğu noktadan öteye gitmez. Birbirlerinden biraz uzakta, birkaç saat geçirdikten sonra Meursault birden Arap'ın olduğu yöne doğru ilerlemeye başlar. Onun kendisine uzaktan biçak çektiğini görünce, “( ...) her şey sallandı. Denizden kalın ve kızgın bir soluk geldi. Sanki gökkubbe ateş yağdırmak için boydan boya yarılıyordu. Bütün vücudum gerildi, elim tabancam üzerinde kasıldı. Tetik oynadı, avcum kabzanın cilalı karnına dokundu. İşte, her şey o kuru, o sağır edici ses içinde başladı" (Camus, 2006: 62-63).

Sömürgeci/sömürülen ya da efendi/köle ilişkisinde sömürülenin başka bir deyişle kölenin bir değerinin olmadığı açıktır. "Toplumsal yaşamda önceden dağıtılmış roller, içine doğduğumuz kimlikle yaşam biçimimizi ve hatta süremizi belirler” (Karadaş, 2018: 42). Görüldüğü gibi öldürülen Arap'ın yaşam süresi edindiği toplumsal kimlikle bağıntılıdır. İçinde bulunduğu toplumla birlikte sömürülenler sınıfında yer aldığından yaşam süresi de kendilerini yöneten sömürgeciler tarafından belirlenir. Arap'ın bir adının olmadığı ve yaşamının ya da ölümünün efendi tarafından belirlendiği bu yapıtta cinayet üzerine yapılan sorgulama da son derece dikkat çekicidir çünkü Meursault her ne kadar birini öldürmekten suçlanıyormuş gibi görünse de gerçekte annesinin cenazesindeki kayıtsızlığı nedeniyle eleştirilip yargılanır. “Ananı sever miydin?" (Camus, 2006: 68), “Ananızı neden ihtiyarlar yurduna koydunuz?" (Camus, 2006: 86) gibi üst üste sorulan soruların yanı sıra, Marie'nin konuşmasının hemen sonrasında birden ayağa kalkan savcının "sayın jüri üyeleri! Bu adam, anası öldükten bir gün sonra deniz banyoları yapıyor, ahlakdışı bir ilişkiye girişiyor ve güldürücü bir filme gidip gönül eğlendiriyor. Sizlere bütün söyleyeceklerim bundan ibaret" (Camus, 2006: 91) demesi, Meursault'nun annesinin ölümündeki ilgisizliğinden dolayı sorgulanmasının ve yine bu nedenle Fransız ulusu adına idam cezası almasının en belirgin göstergeleridir.

Sonuç olarak, Albert Camus'nün Yabancı adlı yapıtında sadece Arap olarak adı geçen, işine, ailesine, çevresine yönelik hiçbir bilgiye yer verilmeyen bu kişinin ölümünün bir öneminin olmadığı kanısına varılır çünkü sömürgecinin gözünde sömürülenin ya da efendinin gözünde kölenin hiçbir değeri yoktur. Öte yandan, sömürgecilerin kendi benliklerini başkalarına kabul ettirmek amacıyla giriştikleri sömürgecilik düzeninde, yaşamları uğruna ne kadar 
savaşırlarsa savaşsınlar hiçbir zaman kendi amaçlarına ulaşamayacakları kesindir. Kölenin efendi olmadan tam olarak özbilincine varamaması gibi, karşılarındaki özneyi bir bilinç olarak kabul etmediklerinden sömürgecilerin ya da efendilerin de yaşamları boyunca diledikleri doyuma ulaşamayacakları açıktır.

\section{Meursault, Contre-Enquête'de efendi-köle görüngüleri}

İnsanlar; kendilerini, güçlerini, benliklerini karşılarındakine kabul ettirmek amacıyla savaşırlar ve her bir savaşın sonunda bir efendi ve köle ortaya çıkar. Başka bir deyişle, tarihsel süreç içinde yaşamını devam ettiren insan, ya efendi ya da köledir; zaten ancak ikisinin olduğu yerde insanın diyalektik varlığından söz edilebilir. Ancak kimi durumlarda, söz konusu iki özne yer değiştirmek zorunda kalır. Bu bölümde de Albert Camus'nün Yabancı adlı romanında yer alan efendinin Kamel Daoud'un Meursault, contre-enquête adlı yapıtında köle konumuna evrilmesi incelenecektir.

1970 yılında Cezayir'de dünyaya gelen Kamel Daoud gazeteci kimliğinin yanı sıra kaleme aldığı yapıtları aracılığıyla adından sıklıkla söz ettirir. Gerek 2002 yılında yayımlanan Raina Raikoum, gerekse öykülerinin bir derlemesini sunduğu Le Minotaure 504 adlı yapıtlarıyla hem Cezayir'de hem de Fransa'da en çok okunan yazarlar arasında yerini alır. 2013 yılında yayımladığı ilk romanı Meursault, contre-enquête ile okurların büyük beğenisini kazanır. Goncourt ödülü alan, otuzdan fazla dile çevrilen ve tiyatroya uyarlanan bu romanında toplumsal gerçekliklerden esinlenir.

Daoud romanı boyunca Camus'ye ve Yabancı'ya göndemeler yapar; zaten onun romanının adı bile bu durumun en belirgin kanıtıdır. Yapıtına Meursault, contre-enquête adını vermesi rastlantısal değildir; başlıkta Meursault adını kullanmayı seçer çünkü bilindiği gibi Meursault Camus'nün romanının başkişisidir. Yapıtın ilk cümleleri de söz konusu durumun göstergelerinden biridir. Yabancl "anam ölmüş bugün. Belki de dün, bilmiyorum" (Camus, 2006: 13) diye başlarken Meursault, contre-enquête' in ilk satırlarını "bugün annem hala sağ" (Daoud, 2014: 7) tümcesi oluşturur.

Romanın ana izleğini, Cezayir'in Oran kentinde yaşayan Haroun adındaki bir kişinin anlattıkları oluşturur. Haroun, Meursault'nun öldürdüğü Arap'ın kardeşidir. Bu Arap’ın gerçek adıyla Moussa'nın bir Fransız tarafından öldürüldüğünü öğrenen annesi çılgına döner; okuma yazma bilmemesine karşın yanına aldığı yedi yaşlarındaki Haroun ile birlikte günlerce Moussa'yı arar. Uzun zaman boyunca Moussa'dan bir iz bulabilmek amaciyla sokak sokak dolaşsalar da bütün çabaları olumsuzlukla sonuçlanır. Bu nedenle ortada bir ceset yokken, Moussa adına Müslüman geleneklerine uygun bir cenaze töreni düzenlerler. Umutlarını tamamen yitirdikleri bir gün Meriem adındaki bir öğrenci kendilerine Camus'nün romanını getirir. Yapıtı büyük bir dikkatle okuyan Haroun böylelikle Moussa'nın başına neler geldiğini, ölümüne kimin neden olduğunu bütün ayrıntılarıyla öğrenir. Kardeşinin içinde bulunduğu durumdan dolayı Camus'yü ve Meursault'yu durmaksızın eleştirir. "Bir adı vardı" (Daoud, 2014: 8) dediği Moussa'nın Yabancı'nın ikinci önemli kişisi olmasına karşın, adına, görüntüsüne, kimliğine yönelik hiçbir bilgiye yer verilmemesini kabullenemez. Bu nedenle çok 
üzülen Haroun, bir yandan Moussa'nın yaşamını ayrıntılı bir biçimde gözler önüne sererken diğer yandan sömürgecilik ve kimlik sorunları üzerinde durur.

Kardeşinin ölümünü sorgulayan Haroun, sömürgeciliği ırkçılık yapmak olarak tanımlar. Fransızların kendi ülkelerinde Araplara karşı olan tutumlarına sıklıkla değinirken, onların kendilerini insan olarak bile görmediklerini belirtir. Sömürgecilere göre "tek karanlık Araplar'ın karanlığıdır” (Daoud, 2014: 8) ve Haroun annesi ile birlikte kardeşini aramak için gittiği Fransız mahallelerinde, daha çok küçük yaşta bu durumun ayrımına varır. Sömürgecilerin küçümseyici bakışlarından kendilerinin oralarda birer davetsiz misafir olduklarını sezinler. Bu nedenle Haroun onların her birinin gerçekte kendi sokaklarında bir Arap, bir Müslüman, bir Haroun ya da bir Moussa olduklarını açıkça belirtir. Arapların adlarının yanı sıra, yüzlerinin, ailelerinin, arkadaşlarının, sevdiklerinin kısacası birer kimliklerinin olduğuna vurgu yapar.

Haroun, kimliklerini, dinlerini, dillerini tamamen yok etmeyi amaçlayan ve kendi dillerini ve dinlerini onlara zorla benimsetmeye çalışan sömürgecilerin varsıllık içinde yaşarlarken, sömürülenlerin zaman kavramlarını yitirdiklerini, kıtlık ve salgın hastalıklarla savaşmak zorunda kaldıklarını da anlatır. Okula başladığı ilk gün sınıfta kendisiyle birlikte iki Arap çocuğu olduklarını ve ikisinin de çıplak ayaklarını belleğinden asla silemediğini üzülerek dile getirir. Çocukluğunun bu kötü anılarına yer veren Haroun bir gün önce hep birlikte oyun oynadığı arkadaşlarından birinin ertesi gün gelmediğinde onun öldüğünü düşünüp oyunlarına devam ettiklerini anlatır.

Söz konusu roman efendi-köle diyalektiği bağlamında ele alındığında, öncelikle üzerinde durulması gereken nokta, Camus'nün yapıtında efendi olarak yer alan sömürgecilerin durumudur. Köleyi egemenliği altına alan efendi her ne kadar bağımsız gibi görünse de onun içinde bulunduğu konum zaman içinde köklü bir değişime uğrar. Bunun nedeni kendisi tarafından tanındığı köleyi ya da sömürülenleri insan olarak kabullenmemesidir. Bu durum efendiyi içinde bulunduğu ortamı sorgulamaya iter çünkü insan olarak kabul etmediği biri tarafından kabullenilir. Böylelikle varoluşsal bir çıkmaza sürüklenirken sözde-efendi haline gelir (Kojève, 2001: 70).

Efendi günden güne dipsiz kuyulara sürüklenirken, onunla ilişkisini nesneler üzerinden gerçekleştiren kölenin durumu da değişmeye başlar. Kölenin "varoluşu, Efendinin Hizmetine (Dienst) yönelik olarak gerçekleştirdiği çalışmayla (Arbeit) sınırlıdır (ona indirgenmiştir). Köle çalışır, ama mücadele etmez (savaşmaz) / ve Hegel'e göre, bir başkasına hizmet için gerçekleştirilen eylem sözcüğün tam anlamıyla «Çalışmadır» (Arbeit) ve özce insansal ve insansallaştıran bir eylemdir ancak" (Kojève, 2001: 47). Kölenin kendi içgüdüleri doğrultusunda çalışmadığı kuşkusuzdur; onun çalışmasının altında yatan neden efendinin kendisinde yarattığ 1 korkudur. Ancak köle zaman içinde durumu kendinden yana çevirmeyi başarır. Efendinin korkusuyla giriştiği çalışma; kölenin özgürlügüne açılan kapıda bir yol gösterici konumuna geçer.

Görüldüğü gibi, "kölenin tözsel niteliği ve içselliği olan çalışma ya da emek, bağımsızlaşmak isteyen bilinci geliştiren başlıca etmendir” (Kula, 2010: 313). Sömürülenlerin de uzun yıllar boyunca efendileri için çalışmaları ve doğada bulunan nesneleri dönüştürmeleri onları günden güne bilinçlenmeye yöneltir. Başlangıçta ölümü göze alamadıkları için köle olmak 
zorunda kalan ama zamanla doğayı işleyebildiklerinin ayrımına varan sömürülenler/Araplar, sömürgecilere/Fransızlara karşı başkaldırırlar. Sömürgeciler nedeniyle kendi ülkelerinde, evlerinde mutlu bir yaşam süremediklerini öne süren sömürülenler, 1950'li yıllarda kadınerkek, genç-yaşlı hep birlikte ayaklanmalara, eylemlere ve isyanlara girişirler. Fransızlar bu ayaklanmaları bastırmak amacıyla birçok uygulamaya yönelseler de “(...) bir tasarı eşliğinde, belli amaçlarla nesneyi dönüştüren (...), veri olanı, doğayı, aşabileceğini, bu anlamda, özgür olduğunu ve böyle olan tek varlık olduğunu” (Bumin, 2010:44) anlayan sömürgeciler artık vazgeçmezler. Gerek satın alıp okudukları gazeteler aracılığıyla gerekse dinledikleri radyonun yardımıyla bilinçlenirler ve direnişe devam ederler. Nitekim doğaya biçim verdikçe öznenin nesneye olan üstünlüğünü ayrımsayan sömürülenler sekiz yıl süren savaşın sonunda 1962 yılında bağımsızlıklarına kavuşurlar.

Yaşadıkları bütün olumsuzluklara karşın büyük bir başarı elde eden sömürülenler efendi konumuna yükselirler. Savaşta yenilgiye uğrayan sömürgeciler de hemen kendi ülkelerine geri dönmeye çalışırlar. Giderken arkalarında "genellikle üç şey bırakırlar: kemikler, yollar ve kelimeler - ya da ölüler...” (Daoud, 2014: 24). Ülkelerine kaçamayan Fransızlar ise bu kez tarihte köle olarak yerlerini alırlar.

Bundan böyle yaşamlarına efendi olarak devam eden Araplar, boyundurukları altında yaşamak zorunda kaldıkları Fransızlara büyük bir kin duyumsarlar. Sömürgecilerin kendilerine yaptıklarının hiçbirini unutmadıkları gibi, karşılaştıkları bütün sıkıntıların öcünü almak isterler. Haroun ve özellikle annesi de intikam ateşiyle yanıp tutuşanlar arasındadırlar. Yıllar önce eşini kaybeden genç kadın büyük oğlu Moussa aracılığıyla ayakta kalmayı başarır ama onun da ölümü üzerine yıkılır. Annenin oğlu için yas tutmaya bile zamanı olmaz çünkü kendisinin ve küçük oğlu Haroun'un gereksinimlerini karşılayabilmek amacıyla hemen çalışmaya koyulur; kimi zaman evlere temizliğe gider kimi zaman da baharat satar. Eşine ve oğluna olan özlemini gidermek için Haroun'a sığınsa da hiç mutlu değildir, sürekli Moussa'yı öldürenlerden öç almanın düşündedir.

1962 yılında Cezayir bağımsızlığına kavuştuktan hemen sonra Haroun ve annesi bağımsızlıklarını ve efendi konumuna yükselmelerini yeni bir ev ile kutlarlar. Arkalarına bile bakmadan kaçan sömürgecilerin bıraktıkları evlerden birine yerleşirler ve uzun zaman sonra ilk kez, anne oğul kendi aralarında eğlenirler. Kahvelerini yudumlarlarken dışarıdan bir ses duyup irkilirler. Gittikçe daha çok artan ses nedeniyle ürküntüye kapılırlar. Önde Haroun, arkasında annesi çıkıp baktıklarında, güçlükle nefes alan Joseph adındaki Fransız'ı bulurlar. Onları görünce çok korkan Joseph hiçbir şey yapmaz; olduğu yerde kımıldamaz bile. Joseph'in suçsuz olduğu ve kendilerine bir zarar vermek için gelmediği kuşkusuzdur ancak Haroun'un annesine göre bu kabul edilebilir bir durum değildir. O suçludur çünkü Fransız'dır ve bu yüzden ölmek zorundadır. Haroun annesinin günah keçisi olarak seçtiği Joseph'i yine annesinin baskısıyla öldürür ve tıpkı eleştirdiği Meursault gibi kendisi de katil olur.

Söz konusu durumun en çok dikkat çeken noktası işte tam da burada başlar çünkü savaş döneminde Araplar birçok Fransızı öldürmelerine karşın asla bunun için yargılanmazlar. Ancak Haroun Joseph'i bağımsızlıklarının hemen sonrasında öldürdüğünden tutuklanır. Onun sorgusu da Meursault'nunki gibi ilginçtir; bir Fransız’ı öldürmesi üzerinde çok durulmaz. «Fransız, onu bizimle birlikte savaş sırasında öldürmen gerekti, bu hafta değil” (Daoud, 
2014: 70) tümcesinden de anlaşıldığg gibi neden Cezayir'in bağımsızlığı için savaşmadığından, Fransızları neden savaşta öldürmediğinden sorgulanır ve birden hiçbir açıklama yapılmadan salıverilir.

Sonuç olarak, Kamel Daoud'un Meursault, contre-enquête adlı romanında, hiçbir biçimde çalışmayan ve eylemde bulunmadıkları için de "hakikî insansal varlık olarak var olmayan" (Kojève, 2001: 60) efendilerin sözde-efendilere ve kölelere dönüşmesi büyük ilgi çeker. Bununla birlikte çalıştıkça gücünün ayrımına varan, doğayı dönüştürdükçe de kendi üstünlüğünü anlayan sömürülenlerin ya da kölelerin büyük bir evrim geçirdikleri görülür. Efendilerinin boyunduruğunda onun buyrukları doğrultusunda yaşarken içinde bulundukları durumdan sıyrıldıkları ve özgürlüğün kapılarını kendi elleriyle araladıkları açıktır.

\section{Sonuç}

Georg Wilhelm Friedrich Hegel, tarih boyunca, insanların başka insanlarla ve doğayla olan ilişkilerinde kimi zaman efendi konumunda olup büyük bir üstünlük kurarlarken kimi zaman da köle olarak boyunduruk altında yaşadıklarını belirtir. Başka bir deyişle, güçlerin eşit olmadığı bir ilişkinin sonunda efendi ve kölenin ortaya çıktığını ve bu diyalektiğin de insanlık tarihini oluşturduğunu dile getirir.

Tarihi, efendiliğin ve köleliğin bir diyalektiği olarak açımlayan ve insanın başka bir özneyle ilk ilişkisinin efendi-köle düzleminde oluştuğunu öne süren Hegel'in söz konusu düşünceleri bağlamında, Albert Camus'nün Yabancı ve Kamel Daoud'un Meursault, contreenquête adlı yapıtları irdelenmiştir. Camus'nün Yabancı adlı romanı efendi-köle ilişkisi bağlamında yorumlandığında, efendi olarak adlandırılan sömürgecilerin tıpkı kendileri gibi olan başka bir efendi tarafından tanınmak istemelerine karşın köle tarafından kabul gördükleri açıktır. Ancak onların bu arzularının gerçekleşmesi neredeyse olanaksızdır. Bu bağlamda, başlangıçta yaşamlarını tehlikeye atan efendilerin hiçbir zaman tam anlamıyla doyuma ulaşamayacakları ve bağımsız gibi görünmelerine karşın gerçekte onların da köleler kadar bağımlı oldukları kanısına varılır.

Kamel Daoud'un Meursault, contre-enquête adlı romanı ise söz konusu diyalektik bağlamında ele alındığında, köle ile ilişkisini nesneler üzerinden gerçekleştiren efendinin konumu dikkat çeker. Hiçbir edimde bulunmadan sadece kölenin kendisi için ürettiğini tüketen ve etrafındakilere karşı üstünlük taslayan efendinin bir tutsağa dönüştüğü görülür. Güçlü görünmeye çalışıp kendisini gizlemesine karşın gittikçe özgürlüğünü yitirdiği ve sözde-efendiye evrildiği açıktır. Bununla birlikte, Camus'nün yapıtında sadece Arap olarak adlandırılan sömürülenlerin ya da kölelerin doğada bulunan nesneleri efendileri için dönüştürdükçe kendi güçlerinin ayrımına vardıkları kesindir. Yeteneklerinin gücünü duyumsayarak kendilerini aşan köleler çalıştıkça özerkliklerine varma yolunda önemli adımlar atarlar. Böylelikle kendi kabuklarından kurtulup özbilinçlerine ulaşmak için ilerlerler ve bağımsızlıklarına yelken açarlar. 


\section{Kaynaklar}

Bumin, T. (2010). Hegel bilinç problemi, köle-efendi diyalektiği, praksis felsefesi. İstanbul: Yap1 Kredi. Camus, A. (2006). Yabancı. (çev: V. Günyol), İstanbul: Can.

Daoud, K. (2014). Meursault contre-enquête. France: Actes Sud.

Girard, R. (2007). Romantik yalan ve romansal hakikat. (çev: A. E. İldem), İstanbul: Metis.

Hegel, G.W.F. (2011). Tinin görüngübilimi. (çev: A. Yardıml1), İstanbul: İdea.

Karadaş, N. (2018). Kırbaçsız efendiler zincirsiz köleler: Türk sinemasında iktidar bağlamında efendiköle diyalektiği. Karadeniz Teknik Üniversitesi İletişim Fakültesi Elektronik Dergisi, Say1 15.

Kartal Güngör, T. (2017). Kamel Daoud'un Meursault karşı soruşturma adlı romanında yeniden yazma ve söyleşimcilik. International Journal of Languages’ Education and Teaching, Say1 3.

Kojeve, A. (2001). Hegel felsefesine giriş. (çev: S. Hilav), İstanbul: Yapı Kredi.

Kula, O. B. (2010). Hegel estetiği ve edebiyat kuramı. İstanbul: İstanbul Bilgi Üniversitesi.

Özçınar, Ş. (2007). Kendinin-bilinci ve öteki diyalektiği: Hegel felsefesinde bilincin dolayımı ve nesnelleşmesi. Ankara Üniversitesi, Sosyal Bilimler Enstitüsü, Doktora Tezi.

Said, E. (2013). Şarkiyatçılık. (çev. B. Ülner), İstanbul: Metis. 